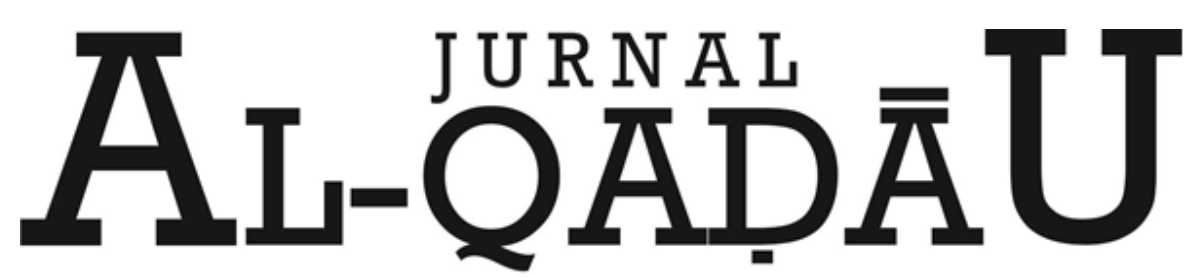

PERADILAN dan HUKUM KELUARGA ISLAM

\title{
PERADILAN AGAMA DI INDONESIA
}

\section{Historya of Existence}

\section{Religious Court in Indonesia}

\section{Jamal Jamil}

Dosen Fakultas Syariah dan Hukum UIN Alauddin Makassar

Email: jamal.jamil@gmail.com

\begin{tabular}{|c|c|}
\hline $\begin{array}{c}\text { Info } \\
\text { Artikel }\end{array}$ & Abstract \\
\hline $\begin{array}{l}\text { Diterima } \\
07 \\
\text { Februari } \\
2018\end{array}$ & $\begin{array}{l}\text { Penelitian ini membahas tentang pengaruh yang ditimbulkan hukum } \\
\text { kolonial Belanda terhadap perkembangan Peradilan Agama di } \\
\text { Indonesia Penelitian ini merupakan library research (penelitian } \\
\text { pustaka) yakni menelah berbagai referensi yang relevan dengan } \\
\text { masalah yang diteliti, menggunakan pendekatan yuridis dan } \\
\text { historis. Metode pengumpulan bersumber dari literatur yang terkait } \\
\text { dengan permasalahan, disajikan secara deskriptif. Kehadiran } \\
\text { hukum kolonial Belanda berdampak positif bagi peradilan agama } \\
\text { di Indoneia, karena sebagai rujukan lahirnya perundang-undangan } \\
\text { peradilan agama di Indonesia. Tanpa adanya beberapa dasar } \\
\text { hukum yang telah ditetapkan pada zaman kolonial Belanda, maka } \\
\text { sejarah peradilan agama tidak mempunyai dasar hukum yang } \\
\text { menggambarkan kondisi peradilan agama pada zaman penjajahan } \\
\text { yang pada akhirnya dapat membentuk undang-undang. }\end{array}$ \\
\hline $\begin{array}{l}\text { Disetujui } \\
24 \\
\text { Mei } \\
2018\end{array}$ & $\begin{array}{l}\text { Kata Kunci: Peradilan Agama } \\
\text { This study discusses the influence of the Dutch colonial law towards } \\
\text { the development of Religious Courts in Indonesia. It is a library } \\
\text { research, defining various relevant references regarding of the } \\
\text { studied concern by using juridical and historical approach. } \\
\text { Collection methods are sourced from the literature related to the } \\
\text { problem, presented descriptively. The presence of Dutch Law had a } \\
\text { positive impact on religious courts in Indonesia, as a reference to } \\
\text { the delivery of religious judicial legislation in Indonesia. In the } \\
\text { absence of some legal basis established in the Dutch colonial era, } \\
\text { the history of the religious judiciary has no legal basis which } \\
\text { describes the conditions of religious courts in the Dutch colonial } \\
\text { era which in the end can form the law. }\end{array}$ \\
\hline
\end{tabular}

Keyword: Religious Court 


\section{A. PENDAHULUAN}

Bagi umat Islam peradilan agama merupakan bagian dari implikasi pelaksanaan syari'at Islam. Dapat disadari, bahwa peradilan agama sudah ada dan tumbuh bersama dengan pertumbuhan agama Islam di setiap negeri daerah yang didatanginya, termasuk Indonesi.

Proses selanjutnya mengenai pertumbuhan agama Islam yang berkembang dengan pesat sepanjang pesisir kepulauan Nusantara. telah membawa perubahan bagi umat Islam Indonesia ke arah pembentukan kelompok-kelompok masyarakat dalam bentuk koordinasi yang lebih baik dan teratur. Dengan adanya lembaga-lembaga peradilan untuk menyelesaikan persoalan dan perkara-perkara yang timbul diantara umat Islam, maka untuk memenuhi kebutuhan kelompok-kelompok masyarakat yang sudah teratur tersebut, pengangkatan hakim atau qadi' dapat dilakukan dengan cara pemilihan dan dibai'at oleh ahlil halli wa al-qadi yakni kelompok-kelompok yang terkemuka dalam masyarakat yang sekaligus merupakan sesepuh adat.

Peradilan agama dilakukan dalam suasana peradilan adat yang sudah melembaga, seperti di daerah Sumatra Barat (Minangkabau) serta daerah-daerah berdirinya kerajaan-kerajaan Islam, maka raja-rajalah yang memberi tauliah yakni memberikan kekuasaan dari pihak penguasa sebagai pelimpahan wewenang pada hakim dan qadi unt uk melakukan tugas-tugas peradilan.

Hanya disayangkan karena kurangnya ditemukan catatan-catatan atau tulisan dari qadi dan alim ulama di masa itu tentang bagaimana peradilan agama dilakukan, sehingga informasi mengenai sejarah peradilan Islam kebanyakan diperoleh dari catatan atau tulisan para sarjana dan ahli hukum bangsa Belanda dan Inggris, sebagai bagian dari ilmu pengetahuan dan hukum adat.

Sejak Belanda datang berkuasa di Indonesia, pada mulanya tidak mencampuri urusan peradilan bagi masyarakat Indonesia, tetapi setelah kekuasaannya dirasakan berkembang clan bertambah kuat, maka mulailah pemerintahan Belanda mencapurinya. Mula-mula diadakan pemisahan antara peradilan keduniawian yang diselenggarakan oleh pengadilan-pengadilan gubernumen, dan pihak lain peradilan agama yang tetap dibiarkan saja berlaku sebagaimana adanya. Hal ini sesuai dengan instruksi pemerintahan Belanda (1982/9) bahwa:

... sedang kepala-kepala pendeta mereka dibiarkan untuk memutus perkaraperkara tertentu dalam bidang-bidang perkawinan dan kewarisan. ${ }^{1}$

Menurut catatan sejarah yang ada menunjukkan bahwa campur tangan Belanda adalah urusan agama Islam dimulai pada saat dikeluarkannya Staatblad 1882 No. 22 berupa instruksi kepada bupati-bupati (Regan Instruksi) untuk mengadakan pengawasan terhadap pelaksanaan peradilan agama Islam.

Campur tangan pemerintah Belanda dalam soal peradilan agama dimulai pada tahun 1820, yaitu dalam instruksi pada bupati-bupati (Regenten Intrudie) pasal 13 disebutkan antara lain bahwa "perselisihan mengenai pembagian waris di kalangan rakyat hendaknya diserahkan kepada para alim ulama Islam".

Kemudian dalam Stbl 1835 No. 58 dinyatakan lebih tegas tentang wewenang "Peradilan Agama" di Jawa dan Madura sebagai berikut: "Jika di antara orang Jawa

${ }^{1}$ H. Z. A. Noeh dan H. A.B. Adrian, Sejarah Singkat Peradilan Agama Islam di Indonesia (Cet. II; Surabaya: FT. Bina Ilmu, 1983), h. 31. 
dengan orang Madura terjadi perselisihan tentang perkara perkawinan atau pembagian harta benda dan sebagainya yang harus diputuskan menurut hukum syara' Islam, maka yang menjatuhkan keputusan dalam hal itu hendaknya betul-betul ahli agama Islam, akan tetapi segala persengketaan dan hal pembagian harta benda atau pembayaran yang terjadi karena keputusan itu harus dibawa ke muka pengadilan biasa. Pengadilan itulah yang akan menyelesaikan perkara itu dengan mengingat keputusan ahli agama dan keputusan itu dijalankan.

Baik dalam Regenten Instructie 1820 maupun Stbl. 1835 No. 58 yang kemudian mendapat perubahan pada tahun 1818 dan tahun 1854, hanya disebutkan penyerahan penyelesaian perkara itu kepada alim ulama/ahli agama Islam yang dalam bahasa Belanda disebut dengan "Priesters", yang dimaksud adalah para penghulu serta pejabatpejabat agama lainnya yang pada waktu itu menjadi pembantu para Bupati. Tetapi di kala itu belum diatur adanya badan peradilan agama itu sendiri, peraturan untuk itu baru di keluarkan pada tahun 1882 .

Campur tangan selanjutnya yang dilakukan oleh pemerintah Belanda terhadap penerbitan Badan Peradilan Islam dimulai setelah raja Belanda mengeluarkan keputusan No. 24 tanggal 19 Januari 1882 tentang Pelembagaan Peradilan Agama di Jawa dan Madura. Keputusan tersebut dimuat dalam Staatblad 1881 No. 152 dan dinyatakan berlaku tanggal 1 Agustus $1882 .^{2}$

Dalam usaha untuk menertibkan peradilan agama, maka oleh Raja Belanda dikeluarkan sebuah keputusan No. 24 tertanggal 19 Januari 1882, dimuat dalam Stbl. 1882 No. 152 tentang pembentukan Pengadilan Agama di Jawa dan Madura, dalam bahasa Belanda disebut: "Bepaling betreffende de Priester raden op Java en Madoera "dan untuk singkatnya selalu disebut Stbl 1882 No. 152. Keputusan Raja ini dinyatakan berlaku mulai tanggal 1 Agustus 1882 termuat dalam Stbl. 1882 No. 153.

Keputusan ini mula-mula hanya berisikan 7 buah pasal, yang maksudnya adalah sebagai berikut:

1. Di samping tiap-tiap landraad (Pengadilan Negeri) diadakan Pengadilan agama, yang mempunyai daerah hukum yang sama.

2. Pengadilan Agama terdiri atas penghulu yang diperbantukan pada landraad sebagai ketua dan sedikit-sedikitnya 8 orang serta sebanyak-banyaknya 8 orang ulama Islam sebagai anggota.

3. Pengadilan Agama tidak boleh mengambil keputusan jika tidak ada sedikitdikitnya 3 orang anggota, termasuk ketuanya hadir. Dalam keadaan perimbangan suara, maka ketua yang menentukan.

4. Keputusan-keputusan pengadilan Agama harus dinyatakan dalam surat yang memuat pertimbangan-pertimbangan dan alasan secara singkat serta ditanda tangani oleh anggota-anggota yang hadir, begitu pula dicatat biaya perkara yang dibebankan kepada yang berperkara.

5. Kepada kedua belah pihak yang berperkara harus diberikan salinan surat keputusan yang ditanda tangani oleh ketua. 
6. Keputusan-keputusan Pengadilan Agama harus dimuat dalam surat register yang setiap 3 bulan sekali harus disampaikan kepada Kepala Daerah setempat (Bupati atau lain-lainnya) untuk memperoleh penyaksian (visum) dari padanya.

7. Keputusan-keputusan Pengadilan Agama yang melampaui batas kekuasaannya atau tidak memenuhi ketentuan ayat 2, 3 dan 4 di atas tidak dapat dinyatakan berlaku.

Hal yang perlu diungkapkan adalah bahwa kehadiran Belanda di satu sisi, membatasi gerak langkah umat Islam atau masyarakat Indonesia dan mengamalkan ajaran Islam (kasus/perkara yang berkaitan dalam bidang perkawinan dan kewarisan). Di sisi lain, kehadiran pemerintah Belanda pulalah yang mengawali terbentuknya undang-undang mengenai peradilan agama sekalipun sangat dibatasi hanya dalam ruang lingkup Jawa dan Madura, luar Jawa dan Madura serta Kalimantan Selatan dan Kalimantan Timur.

Dari uraian yang telah disebutkan di atas, maka pokok permasalahan yang muncul dalam pembahasan tulisan ini adalah sejauh mana pengaruh yang ditimbulkan Hukum kolonial Belanda terhadap perkembangan Peradilan Agama di Indonesia?

\section{B. METODE PENELITIAN}

Jenis penelitian ini merupakan library research (penelitian pustaka) yakni menelah berbagai referensi yang relevan dengan masalah yang diteliti, menggunakan pendekatan yuridis dan historis.

Metode pengumpulan bersumber dari : 1. Data Primer, yaitu data yang diperoleh diperoleh dari berbagai literatur yang terkait dengan permasalahan., 2. Data Sekunder, yaitu data yang diperoleh dari berbagai literatur, peraturan perundang-undangan, pendapat para ahli hukum, dokumen serta tulisan lain yang terkait materi yang dibahas sebagai penunjang.

Data yang berhasil diperoleh atau yang berhasil dikumpulkan selama proses penelitian baik itu data primer dan sekunder dianalisis secara kualitatif kemudian disajikan secara deskriptif yaitu menguraikan, menggambarkan, dan menjelaskan sesuai dengan permasalahan yang erat kaitannya dengan penelitian ini

\section{PEMBAHASAN}

\section{PERADILAN AGAMA DI INDONESIA DAN PENGARUHNYA HUKUM KOLONIAL BELANDA}

Pengaruh yang ditimbulkan Hukum kolonial Belanda yakni di satu sisi dikatakan berdampak positif dan di sisi lain berdampak negatif. Dampak positif yang penulis maksudkan adalah sejarah peradilan agama telah membawa proses yang sangat penting terhadap terbentuknya beberapa peraturan yang terkait dengan kemajuan dan kekuatan peradilan agama di negara Pancasila ini. Tanpa adanya beberapa dasar hukum yang telah ditetapkan pada zaman kolonial Belanda, maka sejarah peradilan agama tidak mempunyai dasar hukum yang menggambarkan kondisi peradilan agama pada zaman penjajahan yang pada akhirnya dapat membentuk undang-undang.

Sedangkan dampak negatif yang telah ditimbulkannya pemerintah kolonial Belanda adalah bahwa umat Islam pada zaman tersebut sangat dibatasi ruang lingkupnya dan bahkan boleh dikatakan bahwa pemerintah kolonial Belanda tidak setuju terhadap adanya peradilan agama, hanya saja kehadiran pemerintah kolonial 
Belanda mempunyai target utama di antaranya mengeruk hasil kekayaan bumi Nusantara dan untuk memperlancar tujuan utama para penjajah, maka mereka memberikan jalan sedikit demi sedikit terhadap keberadaan peradilan agama. Hal ini dapat dilihat dalam berbagai tulisan di antaranya oleh H. Ichatijanto, SA., SH., dalam Pengembangan Teori Berlakunya Hukum Islam di Indonesia., sebagaimana dikutip oleh Juhaya S. Praja, beliau mengungkapkan bahwa dalam perkembangan pengkajian hukum Islam di Indonesia, dilihat ada beberapa teori tentang berlakunya hukum Islam di Indonesia yang tergambar pada uraian berikut: ${ }^{3}$

\section{a. Ajaran Islam tentang penataan hukum. ${ }^{4}$}

Dalam al-Qur'an banyak ketentuan bahwa kepada orang Islam pada dasarnya diperintahkan untuk taat kepada Allah dan Rasul-Nya. Orang Islam tidak dibenarkan mengambil pilihan lain kalau ternyata Allah dan Rasul-Nya telah menetapkan hukum yang pasti dan jelas.

Hal tersebut merupakan prinsip keyakinan agama dan keyakinan hukum serta merupakan kelanjutan dari keyakinan mengEsa-kan Tuhan di dalam hukum (tauhid al-tasyri) . Oleh karena itu, dari segi ajaran Islam sendiri, tanpa dikaitkan dengan keadaan hukum di masyarakat, berlaku prinsip bagi orang Islam berlaku hukum Islam. ${ }^{5}$

\section{b. Teori penerimaan autoritas hukum 6}

Teori ini menyatakan bahwa orang Islam, kalau telah menerima Islam sebagai agamanya, ia menerima autoritas hukum Islam terhadap dirinya. Secara sosiologis, orang-orang yang sudah beragama Islam menerima autoritas hukum Islam, taat kepada hukum Islam. Tingkatan ketaatan tiap manusia mesti berbedabeda, bergantung pada takwanya kepada Allah.

\section{c. Teori Receptie in Complexu ${ }^{7}$}

Semenjak sebelum 1800 dan tahun-tahun sesudahnya itu telah diakui oleh para ahli hukum dan ahli kebudayaan Belanda sendiri bahwa di Indonesia berlaku hukum Islam. Oleh karena itu, politik hukum dalam peradilan pun diberlakukan undang-undang agama Islam untuk orang penduduk asli itu. Masa itu dikenal dengan nama receptio in complexu. ${ }^{8}$

Teori ini dimunculkan oleh Van den Berg berdasarkan kenyataan bahwa hukum Islam diterima (diresepsi) secara menyeluruh oleh umat Islam. Apa yang telah berlaku sejak mulai adanya kerajaan-kerajaan Islam di nusantara, sejak

\footnotetext{
${ }^{3}$ Juhaya S. Praja, Hukum Islam di Indonesia Perkembangan dan Pembentukannya (Bandung: Remaja Rosdakarya, 1991), h. 101. QS: 1: 5, QS: 2: 179, QS: 4: 13-14, QS: 4: 49, 63, 105, QS: 5: 44, 47, 48, 49, 50, QS: 24: 51, 52.

${ }^{4}$ Juhaya S. Praja, Hukum Islam di Indonesia Perkembangan dan Pembentukannya.

${ }^{5}$ H. A. R. Gibb dalam bukunya, The Modern Trends of Islam, menyatakan bahwa kalau orang Islam telah menerima Islam sebagai agamanya, maka ia menerima autoritas hukum Islam terhadap dirinya. Teori yang mengatakan bahwa hukum yang berlaku pada rakyat pribumi adalah hukum agamanya

${ }^{6}$ Sajuti Thalib, Receptio A Conhario : Hubungan Hukum Adat dengan Hukum Islam (Cet. IV; Jakarta: Bina Aksara, 1985), h. 4

${ }^{7}$ Ismail Sunny, Kedudukan Hukum Islam dalam Sistem Ketatanegaraan Indonesia, dalam Amrullah Ahmad, h.131.

${ }^{8}$ Arso Sostroatmojo dan A. Wasit Aulawi, Hukum Perkawinan di Indonesia (Jakarta: Bulan Bintang, t.th), h. 11-12.
} 
kedatangan VOC hukum kekeluargaan Islam, hukum perkawinan dan hukum waris tetap diakui oleh Belanda. Bahkan oleh VOC, hukum kekeluargaan itu diakui dan dilaksanakan dengan bentuk peraturan Resolutie der Indische Regeering tanggal 25 Mei 1760 yang merupakan kumpulan aturan hukum perkawinan dan hukum kewarisan Islam dan terkenal sebagai Compendium Freijer. Hukum Islam yang telah berlaku dari zaman VOC itulah oleh pemerintah Hindia Belanda diberikan dasar hukumnya dalam RR tahun 1855 yang antara lain dinyatakan dalam pasal 75: Oleh hakim Indonesia itu hendaklah diperlakukan undang-undang agama (Godsdienstige wettwn)..."9

Berdasarkan hal tersebut, oleh para ahli Belanda dibuatlah berbagai kumpulan hukum untuk pedoman pejabat dalam penyelesaian urusan-urusan hukum rakyat pribumi, yang tinggal di wilayah yang dikuasai VOC, kemudian Nederlandsch Indie, yang terkenal adalah sebagai berikut:

1. Compendium Freijer yang merupakan kitab hukum kumpulan hukum perkawinan dan hukum kewarisan Islam oleh Pengadilan VOC (Resolutie der Indische Regeering tanggal 25 Mei 1760).

2. Cribonsch Rechboek yang dibuat atas usul Residen Cirebon (Mr.P.C. Hosselaar, 1757-1765).

3. Compendium der Voornaamste Javaansche Wetten nauwkeuring getrokken uit het Mohammedaansche Wetboek Mogharraer, dibuat untuk Landraad Semarang (tahun 1750).

4. Compendium Inlansche Wetten bij de Hoven van Bone en Gowa, disahkan oleh VOC untuk daerah Makassar. ${ }^{10}$

Tampaknya teori receptio in complexu muncul sebagai rumusan dari keadaan hukum yang ada dan bersumber dari prinsip hukum Islam bahwa bagi orang Islam berlaku hukum Islam. Van den Berg mengonsepkan Stbl. 1882 No. 152 yang berisi ketentuan bahwa bagi rakyat pribumi atau rakyat jajahan berlaku hukum agamanya yang berada dalam lingkungan hidupnya. Praktisnya, yang berlaku untuk rakyat jajahan yang beragama Islam di Indonesia adalah hukum Islam. Karena yang berlaku ketentuan atau norma hukum Islam, maka badan-badan peradilan agama, yang pada waktu pemerintahan Hindia Belanda datang ke Indonesia sudah ada dilanjutkan diakui kewenangan hukumnya.

d. Teori Receptie ${ }^{11}$

Teori ini dikemukakan oleh Prof. Christian Snouck Horgronye (1857-1936), kemudian dikembangkan oleh C. Van Vallenhoven dan Ter Haar.

C. S. Hurgronye yang di kalangan umat Islam di Indonesia dikenal sangat anti Islam menentang pendapat L.W.C. Van den Berg dan ahli lain sebelum itu yang dikenal dengan teori receptie in complexu tersebut. Teori receptio menyatakan bahwa bagi rakyat pribumi pada dasarnya berlaku hukum adat. Hukum Islam berlaku kalau norma hukum Islam itu telah diterima (diresepsi) oleh

\footnotetext{
${ }^{9}$ Teori ini menyatakan bahwa hukum yang berlaku bagi rakyat jajahan adalah hukum adat, hukum Islam menjadi hukum kaiau diterima oleh masyarakat sebagai hukum adat.

${ }^{10}$ Ichtijanto, Pengembangan Teori Berlakunya Hukum Islam diIndonesia dan Tjun Surjaman (eel). Hukum Islam di Indonesia Perkembangan dan Pembentukan (Cet. I; Bandung: Remaja Rosdakarya, 1991), h. 122-123.

${ }^{11}$ Aqib Suminto, Politik Islam Hindia Belanda (Jakarta: LP3ES), h. 11.
} 
masyarakat sebagai hukum adat. Teori ini berpangkal dari keinginan Snouck Hurgronye agar orang-orang pribumi rakyat jajahan jangan sampai kuat memegang Islam, sebab pada umumnya orang-orang yang kuat memegang agama Islam dan hukum Islam tidak mudah dipengaruhi oleh peradaban Barat. Snouck Hurgronye mengemukakan teori ini karena ia khawatir pengaruh Pan-Islamisrne yang dipelopori, oleh Sayid Jamaluddin al-Afgani berpengaruh di Indonesia. Ia merumuskan saran kepada pemerintah Belanda tentang kebijaksanaan terhadap Islam yang dikenal dengan Islam policy. ${ }^{12}$

Bagi Snouck Hurgronye, musuh kolonialisme bukanlah Islam sebagai agama, melainkan Islam sebagai doktrin politik. Hal ini timbui, karena ia melihat kenyataan bahwa Islam seringkali menimbulkan bahaya terhadap kekuasaan Belanda. ${ }^{13}$ Meskipun Islam di Indonesia terkesan banyak bercampur dengan kepercayaan animisme dan Hindu, ia tahu bahwa orang Islam di negeri ini memandang agamanya sebagai alat pengikat kuat yang membedakan diri dari orang lain. Melalui usaha terus menerus dan sistematis, kolonial Belanda mengganti teori receptie in complexu menjadi teori receptie. Pasal 134 ayat (2) IS menyatakan: "Dalam hal terjadi perkara perdata antara sesama orang Islam akan diselesaikan oleh hakim agama Islam apabila tersebut telah diterima oleh hukum adat mereka dan sejauh tidak ditentukan lain oleh ordonansi". ${ }^{14}$

e. Teori Receptie Exit ${ }^{15}$

Dalam bukunya, Tujuh Serangkai tentang Hukum, pandangan Prof. Dr. Hazairin, S.H. tentang fungsi hukum dan hukum Islam serta sumber hukum Islam. Prof. Hazairin berpendirian bahwa setelah Indonesia merdeka, setelah Proklamasi dan setelah UUD 1945 dijadikan UUD negara, maka walaupun aturan peralihan menyatakan bahwa hukum yang lama masih berlaku selama jiwanya tidak bertentangan dengan UUD 1945, seluruh peraturan perundang-undangan pemerintah Hindia Belanda yang berdasarkan ajaran teori receptie tidak berlaku lagi karena jiwanya bertentangan UUD 1945.

Teori receptie harus exit karena bertentangan dengan al-Qur'an dan Sunnah Rasul. Prof. Dr. Hazairin juga menyebut bahwa teori recepti adalah teori iblis. la berpendirian bahwa kemerdekaan Indonesia mempunyai arti besar terhadap berlakunya ajaran hukum yang harus ditaati di Indonesia. ${ }^{16}$

\section{f. Teori receptie a contrario ${ }^{17}$}

Teori ini mengatakan Hukum adat baru berlaku kalau tidak bertentangan dengan hukum Islam. Teori ini antitesa terhadap teori receptie.

\footnotetext{
${ }^{12}$ Daliar Noer, The Modernist Muslim Movement in Indonesia 19001942 (London: KL: 1973), h. 164.

${ }^{13}$ Ismail Sunny, Kedudukan Hukum Islam dalam Sistem Ketatanegaraan Indonesia,h. 194.

${ }^{14}$ Teori receptie exit maksudnya adalah bahwa teori receptie harus keluar dari teori hukum nasional Indonesia karena bertentangan dengan UUD 1945 serta bertentangan dengan al-Qur'an dan Sunnah

${ }^{15}$ Juhaya S. Praja, Hukum Islam di Indonesia Perkembangan dan Pembentukan, h. 128

${ }^{16}$ Teori Receptie a Confrario menyatakan bahwa hukum yang berlaku bagirakyat adalah hukum agamanya, hukum adat hanya berlaku kalau tidak bertentangan dengan hukum agamanya.

${ }^{17}$ Roihan A. Rasyid, Hukum Acara Peradilan Agama (Jakarta : Raja Grafindo Persada, 1994), h. 20.
} 
Kaitannya dengan perkembangan peradilan agama di Indonesia, semua jenis teori-teori hukum tersebut telah menambah khazanah terbentuknya undang-undang peradilan agama secara permanen, yang jauh sebelumnya peradiian agama tidak memiliki undang-undang secara tertulis yang sifatnya masih acak-acakan. Diungkapkan oleh Roihan. A. Rasyid, bahwa untuk melaksanakan tugas peradilan agama, maka dipergunakan acara yang berserak-serakan dalam berbagai peraturan perundang-undangan, bahkan juga acara dalam hukum tidak tertulis (maksudnya hukum formal Islam yang belum diwujudkan dalam bentuk peraturan perundangundangan negara Indonesia), namun kini setelah terbitnya UU No. 7 Tahun 1989 yang mulai berlaku sejak tanggal diundangkannya 29 Desember 1989, dan UU No. 3 Tahun 2006 tentang Revisi UU No. 7 Tahun 1989 maka hukum acara peradilan agama menjadi kongkrit.

\section{KESIMPULAN}

Dari uraian di atas dapat dipahami, bahwa kehadiran hukum kolonial Belanda pada mulanya agar supaya dapat mempersempit ruang gerak umat Islam, khususnya dalam rangka menyelesaikan kasus keperdataan diantara umat Islam, peraturanperaturan atau stabalad pada akhirnya inilah menjadi rujukan lahirnya perundangundangan peradilan agama di Indonesia. Perkembangan peradilan agama yang telah dicatat dalam sejarah merupakan rangkaian perkembangan yang sangat berpengaruh terhadap kemajuan dan peningkatan peradilan agama di Indonesia.

\section{DAFTAR PUSTAKA}

Arso Sostroatmojo dan A. Wasit Aulawi. Hukum Perkawinan di Indonesia. Jakarta: Bulan Bintang. t.th.

Noer, Daliar. The Modernist Muslim Movement in Indonesia 19001942. London: KL: 1973.

Sunny, Ismail. Kedudukan Hukum Islam dalam Sistem Ketatanegaraan Indonesia, dalam Amrullah Ahmad.

Suminto, Aqib. Politik Islam Hindia Belanda. Jakarta: LP3ES I

Ichtijanto. Pengembangan Teori Berlakunya Hukum Islam di Indonesia dan Tjun Surjaman (eel). Hukum Islam di Indonesia Perkembangan dan Pembentukan. Cet. I; Bandung: Remaja Rosdakarya, 1991.

H. Z. A. Noeh dan H. A.B. Adrian. Sejarah Singkat Peradilan Agama Islam di Indonesia. Cet. II; Surabaya: FT. Bina Ilmu, 1983.

H. A. R. Gibb dalam bukunya, The Modern Trends of Islam.

Rasyid, Roihan A. Hukum Acara Peradilan Agama, Jakarta: Raja Grafindo Persada, 1994.

Praja, Juhaya S. Hukum Islam di Indonesia Perkembangan dan Pembentukannya, Bandung: Remaja Rosdakarya. 1991.

Thalib, Sajuti. Receptio A Conhario : Hubungan Hukum Adat dengan Hukum Islam. Cet. IV; Jakarta: Bina Aksara, 1985. 